\title{
A Marriage That Works: An Approach to Administrative Structure in Curriculum Centers
}

\section{Mary Jane Scherdin}

\section{LITTLE UNIFORMITY}

A review of curriculum libraries in academic institutions across the United States leads one to a rapid realization that there is little uniformity in policies, administration, or even in titles. Learning materials centers, instructional materials centers, or curriculum laboratories are other designations for these specialized library centers that are administered either by the school of education, by the main campus library, or by both as a joint venture.

Physical facilities, funding sources, and organizational structures are similarly differentiated. Some are housed in the main library and some in the education building. Generally, resources are derived from the school of education, the library, or both. Most centers include the children's literature collection, textbooks, and curriculum guides for kindergarten through grade twelve. Additionally, some include all nonprint materials and equipment for the campus. Many have the audiovisual production area available for students.

Because of their dual role in serving both the library and the school of education and by reason of their various functions, curriculum centers present unique needs for organizational design. In addition to administering the myriad of elementary and secondary instructional materials used by prospective teachers, they support the academic needs of education faculty and provide specific services both to students and faculty for evaluating and updating materials in order to reflect new methodologies in education. They may also make available facilities for preview, selection, demonstration, and evaluation of all types of audiovisual materials and equipment.
Visits to curriculum centers have shown a diversity of administrative structures as well as a variety of policies and functions. Within the University of Wisconsin System, seven curriculum centers are housed in, staffed by, and financially supported by the main campus library. Two are supported and staffed by the College of Education and are housed in the education building. The first of these is the University of Wisconsin-Madison, where the IMC catalogs through OCLC and thus its collection is highly accessible. The second campus is considering integrating the center into the library's services.

Northern Illinois University's program is similar to the seven UW institutions mentioned above.

The University of Michigan education center, called Instruction Strategy Services, has been funded jointly by the School of Education and Library Science since reorganization in 1979 . Not only does it collect $\mathrm{K}-12$ curricular materials and serve as a resource center for new technology, but the staff teaches audiovisual methods to all education students.

The University of Texas at Austin's curriculum center is housed in the education building and is not a part of the campus library system. Materials are organized by department and not cataloged through OCLC, nor are they recorded in the union card catalog of the main campus library.

Currently the quality of curriculum centers is an issue of increasing importance to both education faculty and library/media staff. Competition among colleges and universities to attract students in education, as well as strict accreditation procedures by the National Council for Accredi- 
tation of Teacher Education (NCATE), have caused increased concern in this regard. A need for high quality and efficient leadership is indicated even more strongly by today's inflated costs combined with limited financial resources. Despite a study concluding that the administrative relationship of the center with other college departments had no significant bearing on the effectiveness of functions or services, actual experience has proven the opposite. ${ }^{1}$ Indeed, the University of Wisconsin-Whitewater has found that close cooperation or joint control between the center and the school of education can play a crucial role in the enhancement of services, the provision of professional consultants, the increase of funding, and the ongoing physical development of the facility.

After a brief historical view and a survey of the relevant literature, this article will present the innovative approach recently adopted at UW-Whitewater which features a joint administrative structure and shared staffing between the university library and the college of education.

\section{HISTORY AND SURVEY OF LITERATURE}

Although the concept of the learning materials center dates back to the 1920 s, there exists little research in the literature of library and information science which deals definitely with the issues of their organization and management. Indeed, only a minimal amount of solid investigation into all operational aspects of such centers has been undertaken. As recently as 1979, Kiewitt and Lehman conducted a survey of policies and practices in 187 centers and recorded that " a thorough search of the literature revealed little ... . information about the current status of curriculum laboratories or materials centers. ${ }^{\prime \prime 2}$

The primary sources for information are the reports (excellent, but not recent) by Elinor Ellis in $1969,{ }^{3}$ Harlan R. Johnson in $1973,{ }^{4}$ Leota Nevil in $1975,{ }^{5}$ and Bertha Boudreau in $1976 .{ }^{6}$ While these studies indicated a general agreement among centers relating to their broader purposes and functions, there was no consensus regarding matters of administration and staffing-areas of concern vital to the establishment of cooperative relationships-or to the effective promotion of essential and innovative services. This factor, along with substantial variations in approaches to funding, collection development, housing, and hours of service among the institutions surveyed, made the formation of evaluative criteria concerning organizational design a difficult task and the accurate perception of general trends in development questionable.

It is apparent that existing hierarchical structures have evolved to fit the mode of operation. Results of the Kiewitt-Lehman study showed that 71 percent of the centers report to the library, while 26 percent report to the school of education. ${ }^{7}$ Ellis found that 56 percent report to the library, 37 percent to the school of education, and 7 percent are joint ventures.

Concerning expenditures, the KiewittLehman study reported that 66 percent receive their funds from the library, 22 percent from education, 7 percent from both, 4 percent from other sources, and 1 percent have no set budget allocation.

Further results of the Kiewitt-Lehman study report that the director or administrator of the center is usually a librarian (78 percent), with 17 percent of the centers supervised by education faculty. The majority (63 percent) were educated both as a librarian and a teacher; 25 percent had only teacher education training.

Additionally, center directors indicated a strong interest in information about other centers and in sharing concern and new ideas. ${ }^{9}$ Presently, staff members wishing to improve their programs must search diligently to collect ideas.

\section{STANDARDS}

The 1960 NCATE standards required the presence of a materials center as a qualification for full accreditation. Later, in 1977, the American Association of Colleges for Teacher Education drafted its standards, which were adopted by NCATE and became effective January 1, 1979. Standard 5.2 states: "A materials and instructional media center for teacher education is maintained either as a part of the library, or as one or more separate 
units, and supports the teacher education program." The standard further elaborates: "A program for the preparation of teachers includes the use of teacherlearning materials and instructional media in two important ways: prospective teachers are instructed in how to devise and use modern technologies in their teaching, and modern technologies are utilized by the faculty in teaching students. ... In maintaining and developing the collection of such materials and media, the institution gives serious consideration to the recommendations of fáculty members and appropriate national professional organizations." ${ }^{10}$

Ellis had indicated in 1969 the problem of a lack of established core standards to be followed by administrators of teacher education programs in planning curriculum centers. ${ }^{11}$ Today, despite the progress that has been made, criteria requisite for specific evaluative purposes are still not available.

\section{UW-WHITEWATER LMC}

The Learning Materials Center (LMC) at the University of Wisconsin-Whitewater, serving a total student population of ten thousand, including approximately 2,700 education students, has successfully -planned and implemented a new organizational design. This approach has resulted in increased usage, a commendation by the NCATE team in 1981, and a new enthusiasm among education faculty and students. An updated collection, better instructional and reference services to users, an attractive physical atmosphere, and more efficiently organized resources are additional by-products of the new administrative structure.

The LMC at UW-Whitewater originated in 1963 as part of the library operation. The collection consisted of textbooks, professional books and filmstrips. In 1965 it was moved to a new addition in the main campus library (Andersen Library), which is in close proximity to the College of Education. Increased demands on the services of the center necessitated a greater variety of materials, both print and non-print. It was a natural growth to have colleges other than the College of Education ask for audio-visual materials in their subject areas. Thus, in December, 1966, the philosophy of the library at UW-Whitewater was broadened to say, "the library is an educational service agency for all areas and departments . . . for all types of instructional aids." The LMC was the most logical area of the library to carry out this mission.

In 1970, another addition was built to the library, and the LMC found its present home of over eleven thousand square feet on the ground floor immediately adjacent to Audiovisual Resources. The latter circulates audiovisual equipment and $16 \mathrm{~mm}$ films while the LMC circulates all other audiovisual software for the campus. The LMC and Audiovisual Resources are two of the seven departments within Library/ Learning Resources at UW-Whitewater. Other departments are acquisitions, cataloging, circulation, information and instruction services, and documents and research collections. The heads of all seven departments report directly to the dean of Library/Learning Resources.

Statistics indicate a high level of usage of the LMC during the early and mid-1970s, followed by a sharp decline. Subsequently the director was moved to another position within the library, and the LMC was made a part of Audiovisual Resources for a year. During the following year the LMC became the responsibility of the Circulation Department. Essentially the center was placed on hold and use dropped even more substantially. There were many complaints by students and faculty, and the College of Education departments began developing satellite collections on their own in departmental offices.

\section{THE NEW ORGANIZATION}

In 1978 the dean of the College of Education approached the dean of Library/ Learning Resources and the vicechancellor for Academic Affairs to seek a solution. A committee representing each department in the College of Education was formed and met during 1978-79.

The committee recommended the following objectives:

a. Provide storage and circulation of educational materials, texts, and media.

b. Offer opportunities to examine, uti- 
lize, and observe materials being used in small group settings through simulations and/or live demonstrations.

c. Offer expertise to support College of Education faculty and students in locating and/or developing instructional materials.

d. Provide seminars and workshops to examine and utilize new instructional materials presented by educational experts or commercial representatives.

e. Provide seminars and workshops to design and create instructional materials for classroom use as presented by educational experts or commercial representatives.

The committee also recommended that ultimate responsibility for management of the LMC should reside with the dean of Library/Learning Resources, but that the College of Education should assume a principal role in management of the LMC. A supervisory committee representing all College of Education departments and Library/Learning Resources should be established and charged with the tasks of development and overview of academic and support services in the LMC as well as center management.

Other recommendations included the phasing out of all departmental collections and satellite centers, yearly financial support from each department of the College of Education and from the College of Education's annual budget, the transfer of current personnel (graduate assistants and work-study students) from departmental collections to the LMC, and staffing of the LMC with a full-time director and a half-time librarian. The committee asked that each department have its own separate area or pod within the LMC and that there be a delivery system from the library to the education building.

\section{AGREEMENT ESTABLISHED}

These suggestions, with some modifications, were incorporated into an agreement between the dean of the College of Education and the dean of Library/Learning Resources which was signed and sent to the vice-chancellor for Academic Affairs in June 1979. Library/Learning Resources agreed to provide:

a. one full-time professional librarian to supervise the operation of the LMC

b. student help to provide assistance in the LMC

c. an initial collection development allocation of five thousand dollars

The College of Education agreed to provide:

a. one full-time faculty position

b. 1.5 graduate assistants

c. encouragement to its departments to designate a substantial part of library funds allocated to each department to purchase materials for the LMC

It was also strongly recommended that the College of Education planning committee continue to function, reporting to the two deans concerning organization of the center, and making recommendations regarding schedules, personnel, and policy guidelines. It was recognized that this preliminary agreement would require modification as the actual implementation was undertaken, i.e., allocations for services, supplies, and capital, and would also require definition of relationships between departments in the College of Education and Library/Learning Resources departments such as Acquisitions and Cataloging. However, it would be important to have the agreement put in writing. Circumstances and administrators do change, and a signed document is a sound basis for future action.

\section{IMPLEMENTATION OF PLAN}

Meanwhile the search had begun for a new director. Consistent with the sharing of responsibilities, the Search and Screen Committee consisted of members from the Library/Learning Resources faculty as well as the College of Education Planning Committee.

The new director began work in July 1979. Immediate tasks included moving four departmental collections; the audiovisual instructional lab; and the children's collection, which had been housed in the campus school. New staff had to be trained and existing resources reorganized.

The College of Education Advisory Committee (as the planning committee was now called) began meeting regularly again to facilitate these tasks. Among their 
concerns was defining the new role of the committee now that the planning of the LMC had been accomplished. It was decided that the group would be advisory in nature but would help set policies and guide the LMC's growth. Input from each department would be given to the director of the LMC and in turn information would be shared with departments regarding new developments in the center.

Under strong leadership from the chair, and with excellent representation from each department, the committee has functioned well and continues to help the LMC become a more integral part of the College of Education. Surveys, flow charts, suggested hours of service, new ideas, and counsel are among the contributions of committee members. They also sponsored two successful open houses. Conversely, the members learned about Library/Learning Resources policies and helped explain to their department colleagues why, for example, it was impractical to maintain their separate collections or pods in the LMC, and why all materials could not be cataloged during the first six weeks.

Advisory Committee meetings are usually held monthly and are attended by the LMC director and frequently by one or both deans. The involvement of the two deans was, and continues to be, crucial in the successful implementation of this joint program.

Planned for the coming year is the selection of a month and a theme by each department in the College of Education, and the setting up of displays, miniworkshops, and programs around that theme. This is to be coordinated through the representatives on the Advisory Committee. Enthusiasm is already high.

One of the key ingredients to success has been the professional position filled by College of Education faculty. Currently this liaison position is held by two halftime faculty members. One person, who has been in the position since the beginning of the renovation, is a member of the Secondary Education Department, and in addition to the LMC duties also teaches a curriculum course and supervises student teachers. The other half-time person, from the Elementary Education Department, teaches reading methods and children's literature courses and also supervises student teachers. It can readily be seen that both have excellent backgrounds to serve LMC goals.

In times of extreme resource and budget constraints, a statewide as well as local campus goal is to retrain existing faculty, when possible, to meet new needs. Therefore, both liaison staffers have had the opportunity to take library/media courses paid for through University of Wisconsin System grants for faculty retraining and renewal. They have also acquired skills through in-service work with local library professionals.

A total of five people have filled this liaison position at various times, some of them on a quarter-time basis. The absolute necessity of continuity and at least halftime participation cannot be overemphasized. However, it is recognized that this goal is difficult to accomplish as class schedules change from semester to semester, faculty members retire, and positions are frozen.

Liaison staff bring expertise in education, particularly in classroom methods to the LMC staff. Education students who are actually working in a classroom situation, as well as those who are in methods classes, gain from the theoretical and practical knowledge of these staff members. Additionally they promote awareness of the LMC among their colleagues in the College of Education. Since they mingle with these staff and students daily, they are in a unique position to "spread the word" about new materials, services, hours, etc., of the LMC.

Likewise, because of their intimate knowledge of instructional programs, the liaison staff are good sources of recommendations for collection development, including updating and weeding. They also encourage donations by College of Education faculty, particularly in the areas of new textbooks and curriculum guides. It is difficult to overstate the value of the informal contact brought by the liaison staff.

Student use is encouraged through tours and classes held in LMC. Tours are 
usually conducted by a liaison staff member. Previous to the tour, plans are made with the class instructor regarding areas to be emphasized and follow-up assignments to be given. The LMC staff member points out relevant materials during each tour on the basis of this discussion. Results: Students have expressed amazement at the holdings of the LMC and regret not knowing about these materials previously. Faculty have written such comments as, "To say we had a successful experience would be understating the situation."

In addition, an attractive atmosphere was created by the installation of carpet, a children's corner featuring a rainbow mural and batik clouds, and comfortable furniture in a periodical reading area. Many students come to study in the LMC even when they don't plan to use its collection.

\section{JOINT VENTURE IS SUCCESSFUL}

Active participation and a new enthusiasm were forthcoming from College of Education faculty as they saw positive changes occurring in the LMC. Their attitude became "This is our center to make as vital and valuable as we can." A byproduct has been increased understanding and respect between College of Education and Library/Learning Resources faculty.

Increased usage in terms of circulation has been 150 percent over a five-year period. Actual figures are

$\begin{array}{cc}\text { Year } & \text { Circulation } \\ 1978-79 & 13,387 \\ 1979-80 & 18,111 \\ 1980-81 & 25,683 \\ 1981-82 & 28,340 \\ 1982-83 & 33,468\end{array}$

The NCATE commendation of the LMC, which came after the team's visit to UW-Whitewater in early 1981, reads as follows:

Resources of the learning center were comprehensive, both in print and non-print material. Equipment was modern and well-maintained. The leadership and service provided by the administration and staff of the learning materials center were found to constitute a particular program strength.
No doubt the attitude of the LMC staff has been one of the important ingredients in the success of this joint venture. Moreover, without the continued support and financial commitment of both deans, the revitalized program would never have become a reality.

The last four years have not been without their frustrations. Overcoming normal staff resistance to change is one element that needs to be considered. Involving the staff in planning and decision-making processes is important.

Because of the additional time and difficulty in cataloging audiovisual and curricular materials, a strong commitment needs to be made by Library/Learning Resources and specifically the Cataloging Department. This support is necessary so these materials have the same accessibility as the traditional book collection.

The dean of the College of Education appoints the liaison staff to serve in the LMC. Selection procedures are enhanced if both the LMC director and the Advisory Committee have input in the assignment. This helps insure a good match. Furthermore, the liaison position needs to be filled by a full-time person (or two halftime persons) on as permanent a basis as possible.

Communication is important. It has been beneficial for each department in the College of Education to hold one of their faculty meetings in the LMC once a year and to discuss plans and needs with the $\mathrm{LMC}$ director. A recent recommendation of the Advisory Committee is that the $\mathrm{LMC}$ be represented in the College of Education administrative staff meetings, especially when matters related to the LMC are discussed. Visibility is needed among those who allocate resources. This is accomplished in Library/Learning $\mathrm{Re}$ sources by the LMC director being a department head.

\section{SUMMARY}

The LMC has become a vital part of the instructional program and a source of satisfaction to users through emphasizing the following:

1. knowledgeable staff available for reference help and orientation 
2. up-to-date materials and equipment

3. a well-organized, fully cataloged, and accessible collection

4. sufficient hours and adequate staffing to serve student needs

5. an attractive, inviting, and comfortable atmosphere for study

6. close communication between LMC staff and College of Education faculty

7. active participation by College of Education faculty in the LMC program and collection

8. written policies that clarify the goals of the LMC and the responsibilities of each administrative unit in carrying them out

The key elements of the program are the location of the center in the library, staffing by both the College of Education and Library/Learning Resources, joint funding, and an advisory committee made up of representatives from each department in the College of Education.

Other departments, such as music and art, may find this same concept useful in planning and administering centers to meet their special needs. The ideas presented here can be used by any department or college that has specialized materials.
Librarians are experienced in the organization and acquisition of materials and in user services. On the other hand, teaching faculty have a wealth of knowledge in their respective subject fields. Members of the teaching faculty can participate with librarians in building the collection and thus develop an interest in making the center the best it can be. With some retraining in library skills, teachers can also perform reference and orientation services for students and colleagues. The heightened awareness caused by these activities will naturally lead to improved use of the center.

The combined efforts of the librarians and teaching faculty-using the best talents of each-can result in a superior contribution to the instructional program.

This approach has proven effective, and the University of Wisconsin-Whitewater's Learning Materials Center continues to move forward. It is the belief of the author that Library/Learning Resources and the College of Education have truly entered into a marriage that works.

\section{REFERENCES}

1. Donald Sidney MacVean, "A Study of Curriculum Laboratories in Midwestern Teacher-Training Institutions" (Ph.D. diss., Univ. of Michigan, 1958), p.146.

2. Eva L. Kiewitt and Lois J. Lehman, Curriculum Materials Centers: A Survey of Their Policies and Practices (Bloomington: Indiana Univ., 1979; ERIC Document Reproduction Service, ED 194 110), p.1.

3. Elinor Ellis, The Role of the Curriculum Laboratory in the Preparation of Quality Teachers (Tallahassee: Florida A\&M Univ., 1969; ERIC Document Reproduction Service, ED 031 457).

4. Harlan R. Johnson, The Curriculum Materials Center: A Study of Policies and Practices in Selected Centers (Flagstaff: Northern Arizona Univ., 1973; ERIC Document Reproduction Service, ED 081449 ).

5. Leota Nevil, A Survey of Curriculum Laboratories in Selected Colleges in Pennsylvania (Wilkes-Barre, Pa.: Wilkes College, 1975; ERIC Document Reproduction Service, ED 112 909).

6. Bertha Boudreau, Selected Curriculum Materials Centers: Organization and Services (Bloomington: Indiana Univ., 1976; ERIC Document Reproduction Service, ED 148 400).

7. Kiewitt and Lehman, Curriculum Materials Centers, p.2-3.

8. Ellis, The Role of the Curriculum Laboratory, p.47.

9. Kiewitt and Lehman, Curriculum Materials Centers, p.2-3.

10. Standards for the Accreditation of Teacher Education (Washington, D.C.: National Council for Accreditation of Teacher Education, 1977) p.10.

11. Ellis, The Role of the Curriculum Laboratory, p.47.

\section{BIBLIOGRAPHY}

Boudreau, Bertha. Selected Curriculum Materials Centers: Organization and Services. Bloomington: Indiana Univ., 1976. ERIC Document Reproduction Service, ED 148400. 
Burlingame, Dwight Francis. A Comparative Study of Organizational Characteristics Used in Learning Resources Centers and Traditionally Organized Library and Audio-Visual Service Facilities in Four Minnesota and Wisconsin Senior Colleges. Bethesda, Md.: ERIC Document Reproduction Service, ED 101 686, 1974.

Church, John G. Administration of Instructional Materials Organizations. Belmont, Calif.: Fearon Publishers, 1970.

Corbacho, Henry Francis. "An Analysis of the Administrative Organization of Selected System Instructional Materials Center Programs." Ph.D. diss., Detroit: Wayne State Univ., 1963.

Ellis, Elinor. The Role of the Curriculum Laboratory in the Preparation of Quality Teachers. Tallahassee: Florida A\&M Univ., 1969. ERIC Document Reproduction Service, ED 031457.

Gallinger, Janice. Educational Media Selection Centers and the Academic Library. Plymouth, N.H.: Plymouth State College, 1974. ERIC Document Reproduction Service, ED 095838.

Houlihan, Bettyjean. "The University Curriculum Library: Evaluate, Update, and Renovate." Curriculum Review 17:361-63 (Dec. 1978).

James, Marian Lucia. "The Curriculum Laboratory in Teacher Education Institutions." Ph.D. diss., Univ. of Connecticut, 1969.

Johnson, Harlan R. The Curriculum Materials Center: A Study of Policies and Practices in Selected Centers. Flagstaff: Northern Arizona Univ., 1973. ERIC Document Reproduction Service, ED 081449.

Kerr, Lucille E. Material Centers: A Dream of Their Future. Park Forest, Ill.: Governors State Univ., 1979. ERIC Document Reproduction Service, ED 188635.

Kiewitt, Eva L., and Lehman, Lois J. Curriculum Materials Centers: A Survey of Their Policies and Practices. Bloomington: Indiana Univ., 1979. ERIC Document Reproduction Service, ED 194110.

MacVean, Donald Sidney. "A Study of Curriculum Laboratories in Midwestern Teacher-Training Institutions." Ph.D. dissertation, Univ. of Michigan, 1958.

Nevil, Leota. A Survey of Curriculum Laboratories in Selected Colleges in Pennsylvania. Wilkes-Barre, Pa.: Wilkes College, 1975. ERIC Document Reproduction Service, ED 112909.

Standards for the Accreditation of Teacher Education. Washington, D.C.: National Council for Accreditation of Teacher Education, 1977.

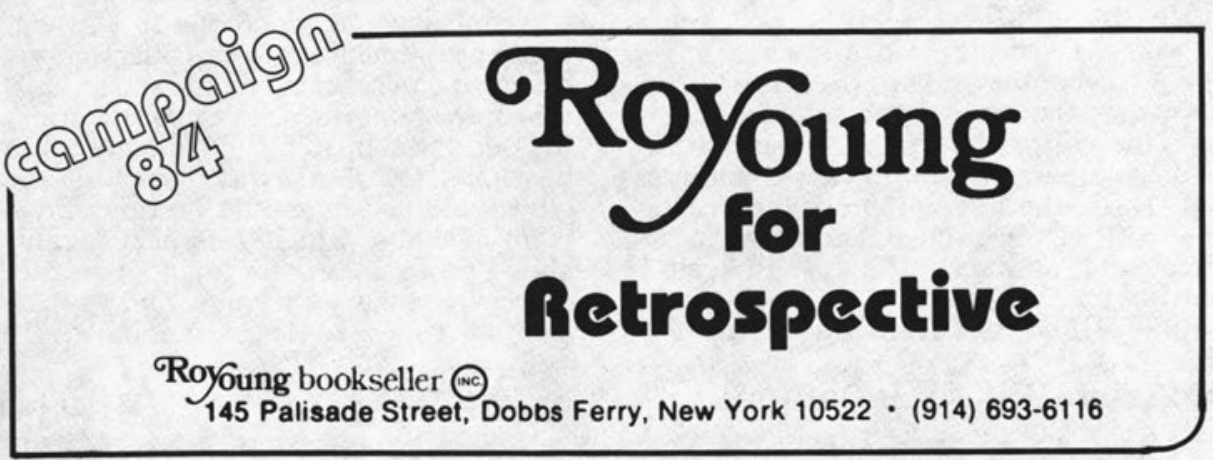




\section{From McGraw-Hill...good news for every budget-conscious librarian}

The whole of today's science and technology covered in a single compact volume!

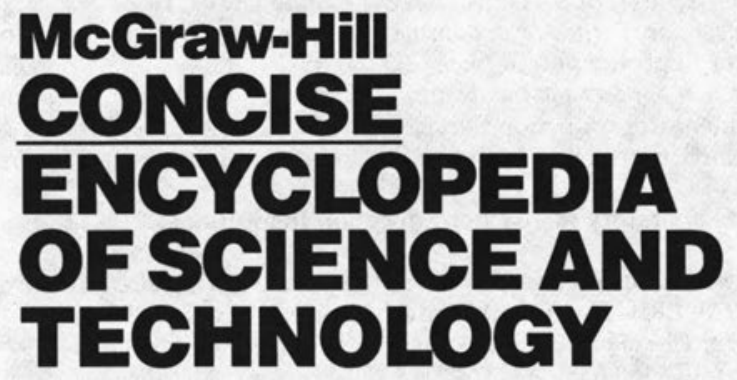

By the Staff of the McGraw-Hill Encyclopedia of Science and Technology - Sybil P. Parker, Editor in Chief 2,200 pages, 1,600 illustrations; $\$ 76.00$ until $6 / 30 / 84$, $\$ 89.50$ thereafter

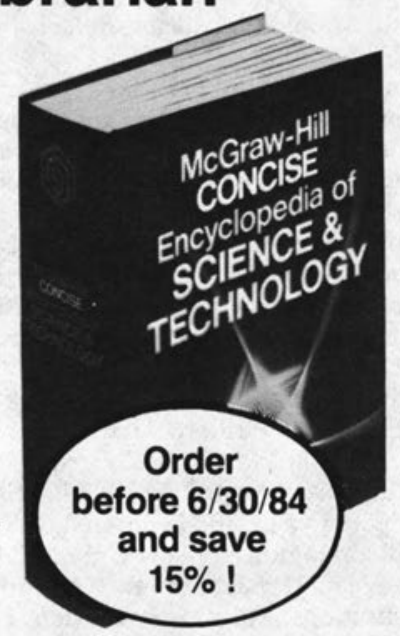

$\mathbf{H}$ ere's good news for every librarian! The most authoritative, up-to-date science reference ever published - the world-famous 15-volume McGraw-Hill Encyclopedia of Science and Technology - is now available for the first time in a new, compact, far less expensive form.

For twenty years, this landmark reference has served as the standard in its field... offering in-depth information on every aspect of science and engineering. So much so, in fact, that it is too comprehensive for the needs of many users.

The new Concise Encyclopedia solves this problem. A streamlined one-volume edition of the multi-volume set, it is designed to present essential information in a practical, convenient format while still maintaining the accuracy, authority, clarity, quality, and broad coverage of the original.

\section{Covers all major topics}

in science and engineering

In preparing the Concise Encyclopedia, the editors extracted the essential text from each article in the 15-volume set. Thus, the one-volume reference is the work of the same 3,000 top authorities who produced the full Encyclopedia - among them 19 Nobel Prize winners. And it covers all of the 75 major topics and areas covered in the larger work, encompassing both basic concepts and advanced technology.

\section{Unique features meet today's} information needs

Like its larger counterpart, the Concise Encyclopedia is right up to the minute on the latest discoveries, and achievements in science and engineering worldwide.

It's organized for fast, easy access, with numerous cross references and a 30,000-entry index. A detailed appendix offers practical tabular help. And many of the 7,300 articles are illustrated-most in two-color for added clarity and ease of comprehension.

More complete than a dictionary - more convenient than a set of encyclopedias

If you haven't added the full 15-volume Encyclopedia to your collection because of space or budget restrictions, this new Concise Encyclopedia offers the perfect solution. What's more, even if your library already contains the multi-volume set, you'll find this convenient new one-volume reference invaluable - as an update for an older edition - or as a backup, alternate, and supplementary source to the current one.

\section{McGraw-Hill Book Company}

1221 Avenue of the Americas, New York, NY 10020

Also available in Canada through McGraw-Hill-Ryerson

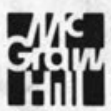

